\title{
How the War Began: Conceptualizing Conflict Escalation in Ukraine's Donbas
}

\author{
Jakob Hauter \\ PhD Student, School of Slavonic and East European Studies, Faculty of \\ Social \& Historical Sciences, University College London, London, UK \\ jakob.hauter.18@ucl.ac.uk
}

\begin{abstract}
This article proposes a new theoretical framework based on conflict escalation theory and the concept of critical junctures to facilitate a more transparent analysis of the war in Ukraine's Donbas. It argues that researchers have proposed a variety of causes of the outbreak of violence in the region. However, in the absence of an overarching theoretical framework, it remains difficult to analyse the interplay of these causes and compare their explanatory power. In response, this article develops a theory-guided escalation sequence model. According to this model, the conflict's formative phase consisted of an escalation sequence that lasted from April until August 2014 and comprised six critical junctures. This article argues that attempts to explain the conflict should be evaluated and compared in terms of their ability to explain these critical junctures. It concludes that similar escalation sequence models could improve research on armed conflict beyond the case of the Donbas.
\end{abstract}

\section{Keywords}

war - armed conflict - escalation - critical junctures - process tracing - Ukraine Donbas 
Scholars of armed conflict have identified a large number of potential causes of war. ${ }^{1}$ Existing studies, however, have not been able to paint a clear picture of the relative importance of these causes and the way in which they interact. A possible explanation for this shortcoming consists of two intertwined challenges.

On the one hand, research on the interaction of different causes of war cannot rely on frequentist inference alone. Because of the coding challenges associated with the variety of proposed causes and the number of potential confounders, correlation analysis has to be supplemented with process-oriented research. In addition to observing that certain factors are often present before the beginning of a war, it is important to understand the specific role that these factors play in the transition from a state of peace to a state of war. ${ }^{2}$

On the other hand, in-depth case studies of individual conflicts are currently largely the domain of historians and area studies specialists. Historical and area studies research often takes the level of analysis to the other extreme and focuses exclusively on the nuances of specific aspects of a conflict. It often lacks the theoretical underpinnings that would enable its findings to feed into a comparative academic discourse.

Addressing these two challenges requires a theoretical framework that can connect the findings of case-study research on the causes of specific wars, so that they can inform comparative research on the causes of war in general. It is the purpose of this article to do so by combining conflict escalation theory-a part of the strategic studies literature that has received relatively little attention since the end of the Cold War-with the historical institutionalist concept of critical junctures. It will demonstrate the benefits of the proposed framework by applying it to the case of the war in Eastern Ukraine's Donets Basin (Donbas). The two challenges described above are particularly pressing in the case of this war because of the diametrical divide it created in the academic

1 See, for example, Lars-Erik Cederman and Manuel Vogt, 'Dynamics and Logics of Civil War', Journal of Conflict Resolution 61, no. 9 (2017): 1992-2016; Jeffrey Dixon, 'What Causes Civil Wars? Integrating Quantitative Research Findings', International Studies Review 11 (2009): 707-735; James D Fearon, 'Rationalist Explanations for War', International Organization 49, no. 3 (1995): 379-414; James D. Fearon and David D. Laitin, 'Ethnicity, Insurgency, and Civil War', American Political Science Review 97, no. 1 (2003): 75-9o; Dan Smith, 'Trends and Causes of Armed Conflict', in Transforming Ethnopolitical Conflict, ed. Alex Austin, Martina Fischer, and Norbert Ropers (Wiesbaden: VS Verlag für Sozialwissenschaften, 2004), 111-127; John A. Vasquez, The War Puzzle (Cambridge: Cambridge, 1993).

2 David Dessler, 'Beyond Correlations: Toward a Causal Theory of War', International Studies Quarterly 35, no. 3 (September 1991): 337-355. 
literature: Some scholars portray the war as a home-grown Ukrainian phenomenon; others portray it as a Russian invasion.

This article will present its argument in four steps. Firstly, it will identify conflict escalation theory as the starting point for a theoretical framework to underpin process-oriented research on the causes of individual conflicts. Secondly, it will introduce the case of the Donbas. It will argue that current analyses of this war lack a common theoretical frame of reference, which makes it impossible to evaluate their arguments in a transparent way and link them to the wider comparative debate. Thirdly, it will construct an initial model in the form of an escalation ladder for the Donbas conflict. Finally, it will use the concept of critical junctures to further refine this initial model and turn it into a robust framework for research on the interplay between different explanatory factors in the genesis of war in the Donbas and beyond.

The idea of a process-oriented 'causal theory of war' has received relatively little attention since it was first proposed by David Dessler, who illustrated the need to look beyond correlations with the metaphor of a thunderstorm. Dessler argues that an exclusive focus on collecting the different geographical and meteorological conditions associated with the occurrence of thunderstorms would lead to a fragmentation of knowledge. Instead, textbook explanations of thunderstorms focus on the 'generative process' that creates them. ${ }^{3}$ Most cases of war also feature a generative process of this kind, namely a period of escalating violence. Hence, this escalation process is the logical starting point for a theoretical framework to underpin a process-oriented, mechanistic evaluation of different causes of war.

An early theorist of war and escalation is 19th century Prussian general Carl von Clausewitz. In the first chapter of his famous work On War, Clausewitz postulates that war has an innate dynamic that drives it to extremes. This dynamic is based on three factors: the fact that war is a reciprocal act of violence without any theoretical limits; the fact that the only way to avert the possibility of defeat is complete victory; and the fact that both sides have to commit everincreasing resources and willpower in the attempt to overthrow each other. ${ }^{4}$

3 Ibid., $342-344$.

4 Carl von Clausewitz, Vom Kriege (Hamburg: Clausewitz-Gesellschaft e.V., 2010), 3-6, https:// bit.ly/2WkA4CZ. 
However, Clausewitz argues that this innate dynamic is moderated by the fact that war is subject to politics. ${ }^{5}$

Escalation became a prominent topic of strategic studies research during the Cold War. Scholars studied escalation processes to assess the likelihood of nuclear war between the two superpowers and find ways to prevent it. Work on escalation dynamics became more explicit and practice oriented. Herman Kahn, for example, suggests that possible scenarios of an armed conflict between the United States and the Soviet Union can be conceptualized through an 'escalation ladder' consisting of 44 steps. The ladder starts with the exchange of diplomatic notes and ends with the indiscriminate use of all available nuclear firepower. ${ }^{6}$ Whereas Kahn only defines escalation in terms of examples, analogies, and conditions, Richard Smoke develops a precise definition. This definition draws on Thomas Schelling's work on 'limited war' - conflict that is characterized by limits to the use of force which the conflict parties choose not to exceed. ${ }^{7}$ Smoke's interpretation of Schelling's work is that virtually all wars are restrained by certain limits which are 'objective, hence noticeable by all parties in the situation' and 'in some fashion discrete or discontinuous'. ${ }^{8}$ He calls these war-restraining limits 'saliencies'. On this basis, Smoke defines escalation as 'an action that crosses a saliency which defines the current limits of a war.' 9

This theoretical work on escalation has received relatively little attention as a potential framework for the analysis of post-Cold War armed conflict. A recent exception is Jan Angstrom and Magnus Petersson's investigation of the strategic rationales of weaker parties that escalate armed conflict with stronger opponents. ${ }^{10}$ Although the study remains theoretical, it is a good example how qualitative research on escalation can create a new line of inquiry for further research on the causes of war. Another exception is a 2012 special issue of the Journal of Strategic Studies titled 'The Escalation and De-Escalation of Irregular War'. In her introduction to this special issue, Isabelle Duyvesteyn follows Smoke's definition of escalation and cites his work extensively. She argues that escalation remains an important concept that can be applied to

$5 \quad$ Ibid., $15^{-17 .}$

6 Herman Kahn, On Escalation. Metaphors and Scenarios (London: Pall Mall Press, 1965), 39-40.

7 Thomas C. Schelling, Arms and Influence (New Haven: Yale University Press, 1966), 129.

8 Richard Smoke, War: Controlling Escalation (Cambridge, MA and London: Harvard University Press, 1977), 32 .

9 Ibid., 35 .

10 Jan Angstrom and Magnus Petersson, 'Weak Party Escalation: An Underestimated Strategy for Small States?', Journal of Strategic Studies 42, no. 2 (February 2019): 282-30o. 
more recent, smaller armed conflicts. ${ }^{11}$ The following contributions in the special issue, however, do not use the work of Smoke, Kahn, or other Cold War theorists. Instead, they base their conceptualizations of escalation on the more general work of Clausewitz. M.L.R. Smith uses the cases of guerrilla warfare in Argentina and Northern Ireland to illustrate how escalation dynamics may work in modern asymmetrical conflict but claims that it is problematic to make generalizations. ${ }^{12}$ John Stone argues that the analysis of the 21st-century 'war on terror' requires a new conceptualization of escalation. ${ }^{13}$ Jan Angstrom and Jan Willem Honig analyse differences in the use of escalation as a strategic instrument by small Western countries participating in the fight against the Taliban in Afghanistan. ${ }^{14}$ David Betz looks at the relationship between escalation and cyberwarfare. ${ }^{15}$ And Martijn Kitzen evaluates the de-escalation strategy used by Dutch forces in Afghanistan's Uruzgan province. ${ }^{16}$ All these contributions address important topics and they all touch on escalation in the context of their specific cases. However, their underlying conceptualization of escalation is too broad to produce a common theoretical framework that could connect their findings. Only in the conclusion to the special issue, Duyvesteyn recalls Smoke's definition and then calls for further research on the topic, in particular for 'more case study material with a specific focus on escalation'.17 The remainder of the present article follows this call by using the case of the Donbas war to create a conflict escalation model which can provide a theoretical framework for research on the causes of this conflict and beyond.

11 Isabelle Duyvesteyn, 'The Escalation and De-Escalation of Irregular War: Setting Out the Problem', Journal of Strategic Studies 35, no. 5 (October 2012): 601-611.

12 M.L.R Smith, 'Escalation in Irregular War: Using Strategic Theory to Examine from First Principles', Journal of Strategic Studies 35, no. 5 (October 2012): 613-637.

13 John Stone, 'Escalation and the War on Terror', Journal of Strategic Studies 35, no. 5 (October 2012): 639-661.

14 Jan Angstrom and Jan Willem Honig, 'Regaining Strategy: Small Powers, Strategic Culture, and Escalation in Afghanistan', Journal of Strategic Studies 35, no. 5 (October 2012): 663-687.

15 David Betz, 'Cyberpower in Strategic Affairs: Neither Unthinkable nor Blessed', Journal of Strategic Studies 35, no. 5 (October 2012): 689-711. For another article on cyberwarfare and escalation, see Erica D. Borghard and Shawn W. Lonergan, 'Cyber Operations as Imperfect Tools of Escalation', Strategic Studies Quarterly 13, no. 3 (Fall 2019): 122-145.

16 Martijn Kitzen, 'Close Encounters of the Tribal Kind: The Implementation of Co-Option as a Tool for De-Escalation of Conflict-The Case of the Netherlands in Afghanistan's Uruzgan Province', Journal of Strategic Studies 35, no. 5 (October 2012): 713-734.

17 Isabelle Duyvesteyn, 'Escalation and De-Escalation of Irregular War: Some Observations and Conclusions', Journal of Strategic Studies 35, no. 5 (October 2012): 740-741. 
The lack of a common theoretical framework is particularly problematic in situations where several scholars researching the same war come to opposite conclusions regarding its causes. This is the case in the academic debate on the war in Ukraine's Donbas. Like the wider political and societal discourse on the topic, the academic debate on this war shows a divide between two different camps. One group of scholars claims that the war was primarily caused by domestic factors with Russian involvement playing a subordinate role. Another group of scholars makes the opposite claim - that local factors played a subordinate role compared to intervention from Moscow. Each narrative has different implications, not only for conflict regulation initiatives but also for the way in which the Donbas war is coded in conflict datasets and used in further comparative research. ${ }^{18}$

Currently, the two contradicting narratives do not share a common theoretical frame of reference. Instead of creating a model of the war before testing their explanations against this model, existing studies of the Donbas conflict inextricably interweave their theoretical assumptions with their empirical analysis. This turns each study into a closed system and makes it impossible to compare the different findings.

Many influential works on the Ukraine crisis pursue a top-down approach when it comes to the war in the Donbas. They do not start their analysis with an investigation of causal relationships between variables in the conflict zone at the time of conflict escalation. Instead, they start with a broader historical or geopolitical narrative and then present the Donbas conflict as an episode which blends into that narrative. The contributions of Michael Aleprete, Paul D'Anieri, Robert Donaldson, or Michael Slobodchikoff, for example, provide important context regarding pre-existing tensions between Russia and Ukraine

18 This section highlights the theoretical shortcomings of this debate by discussing a number of illustrative examples. However, it is not possible to review the entire academic literature on the causes of the Donbas war within the confines of this article. For further reading on the divide in the academic debate and the implications of the war's categorization for policy making and further research, see, for example, Jakob Hauter, 'Delegated Interstate War: Introducing an Addition to Armed Conflict Typologies', Journal of Strategic Security 12, no. 4 (2019); Jakob Hauter (ed.), Civil War? Interstate War? Hybrid War? Dimensions and Interpretations of the Donbas Conflict in 2014-2020 (Stuttgart: ibidem-Verlag, forthcoming); Oleksandr Melnyk, 'From the "Russian Spring" to the Armed Insurrection: Russia, Ukraine and Political Communities in the Donbas and Southern Ukraine', The Soviet and Post-Soviet Review 47, no. 1 (2020): 4-5; Mychailo Wynnyckyj, Ukraine's Maidan, Russia's War: A Chronicle and Analysis of the Revolution of Dignity (Stuttgart: ibidem-Verlag, 2019), 213-239. 
and the role of geopolitical rivalries between Russia and the West. ${ }^{19}$ However, they prioritize the analysis of this wider context over the analysis of events on the ground at the time. This prioritization of the macro-level increases the risk of overlooking or mischaracterizing micro-level dynamics because it tends to presume that these dynamics are either not important or that they fall in line with the macro-level narrative. Moreover, a macro-level approach may lead to historical determinism in the sense that the presented historical narrative affects the interpretation of the facts of the case. Richard Sakwa, for example, emphasizes historical identity cleavages within Ukrainian society and particularly highlights tensions between 'monist' and 'pluralist' approaches to Ukrainian nationhood. ${ }^{20}$ This focus in the choice of historical narrative inevitably sets the scene for a stronger focus on domestic conflict dynamics when it comes to the analysis of the conflict itself. In the work of scholars like Andrew Wilson and Taras Kuzio, on the other hand, an emphasis on nationalist and irredentist tendencies in post-Soviet Russia to some extent predetermines an interpretation of the conflict that focuses more on Russia's actions. ${ }^{21}$

Works with a more direct focus on what happened on the ground in the Donbas in 2014 face a slightly different set of issues regarding conceptual determinism in their theoretical framing. Some studies openly admit to conceptual bias in their choice of explanatory factors. Anna Matveeva writes that her article 'acknowledges the Russian government's role to be a big issue, but abstains from examining it, concentrating on [the] internal dynamic [of the conflict] instead'. ${ }^{22}$ Hence, she arrives at her conclusion that the Donbas conflict 'was leaderless and not spearheaded by [the] elite' within a framework of analysis that excludes Russian intervention a priori. ${ }^{23}$ Mark Galeotti's

19 Michael E. Aleprete, 'Minimizing Loss: Explaining Russian Policy Choices during the Ukrainian Crisis', The Soviet and Post-Soviet Review 44, no. 1 (January 2017): 53-75; Paul D'Anieri, Ukraine and Russia: From Civilized Divorce to Uncivil War (Cambridge: Cambridge University Press, 2019); Robert H. Donaldson, 'The Role of Nato Enlargement in the Ukraine Crisis', The Soviet and Post-Soviet Review 44, no. 1 (January 2017): 32-52; Michael O. Slobodchikoff, 'Challenging US Hegemony: The Ukrainian Crisis and Russian Regional Order', The Soviet and Post-Soviet Review 44, no. 1 (January 2017): 76-95.

20 Richard Sakwa, Frontline Ukraine: Crisis in the Borderlands (London: I.B. Tauris, 2015); Richard Sakwa, 'The Ukraine Syndrome and Europe: Between Norms and Space', The Soviet and Post-Soviet Review 44, no. 1 (January 2017): 9-31.

Taras Kuzio, Putin's War Against Ukraine:Revolution, Nationalism, and Crime (CreateSpace, 2017); Andrew Wilson, Ukraine Crisis. What It Means for the West (New Haven and London: Yale University Press, 2014). Donbass', Southeast European and Black Sea Studies 16, no. 1 (2016): 25.

23 Ibid., 35 . 
conceptual framework of a 'new way of war' and Andrew Bowen's framework of 'coercive diplomacy', on the other hand, a priori emphasize Russia's role as a key actor. ${ }^{24}$ And Vlad Mykhnenko's theoretical approach a priori defines economic factors as the only possible domestic explanation for the outbreak of violence, which means that disproving economic explanations becomes sufficient proof for the primacy of Russia's role. ${ }^{25}$

A more implicit form of conceptual determinism relates to the question of when and where the Donbas conflict began. Serhiy Kudelia and Ivan Katchanovski start their analyses with the outbreak of violence at the Euromaidan protests in Kyiv. ${ }^{26}$ They justify this choice of a starting point by saying that the violence of the Euromaidan caused the formation of a paramilitary countermovement in the East, which started to rebel against the new Kyiv authorities after the Euromaidan's victory. This justification, however, is derived from the authors' conclusion that a domestic dynamic of protest and counterprotest was the key cause of the war. In other words, the theoretical framing of their analysis is dependent on its outcome. Oleksandr Melnyk and Hiroaki Kuromiya are more cautious in their evaluation of the Euromaidan's impact on the Donbas. ${ }^{27}$ Their analyses reject the idea that Donbas society was a pro-Russian monolith that was bound to react to the replacement of the Yanukovych administration with armed separatism. For this reason, their explanation of conflict escalation pays closer attention to the nuances of postEuromaidan societal dynamics within the Donbas and to the importance Russian meddling. However, both Melnyk and Kuromiya end their empirical analysis with the occupation of Sloviansk and Kramatorsk by armed men on 12 April. By choosing this end point, they imply that late February-early April 2014 was the conflict's crucial formative phase, without examining the potential significance of later events.

Another implicit form of conceptual determinism concerns the significance of international agreements and diplomatic statements as a data source.

24 Mark Galeotti, 'Hybrid, Ambiguous, and Non-Linear? How New Is Russia's "New Way of War”?', Small Wars \& Insurgencies 27, no. 2 (2016): 282-301; Andrew S. Bowen, 'Coercive Diplomacy and the Donbas: Explaining Russian Strategy in Eastern Ukraine', Journal of Strategic Studies 42, no. 3-4 (June 2019): 312-343.

25 Vlad Mykhnenko, 'Causes and Consequences of the War in Eastern Ukraine: An Economic Geography Perspective', Europe-Asia Studies (February 2020):1-33.

26 Serhiy Kudelia, 'The Donbas Rift', Russian Politics \& Law 54, no. 1 (2016): 7-10; Ivan Katchanovski, 'The Separatist War in Donbas: A Violent Break-up of Ukraine?', European Politics and Society 17, no. 4 (2016): 477-479.

27 Hiroaki Kuromiya, 'The War in the Donbas in Historical Perspective', The Soviet and Post-Soviet Review 46, no. 3 (August 2019): 251-258; Melnyk, 'From the "Russian Spring" to the Armed Insurrection', 6-37. 
Tatyana Malyarenko and Stefan Wolff, for example, define four conflict regulation agreements as cornerstones of their analysis of Russia's logic of "competitive influence-seeking" in the Donbas. ${ }^{28}$ This conceptual setup, however, rests on the assumption that all of these agreements had a significant impact on the course of the conflict. Lance Davies and Paul Robinson, on the other hand, analyse Russia's involvement in the conflict on the basis of a model that implicitly defines statements by Russian officials as indicators of Moscow's intentions and objectives. ${ }^{29}$ They use this model to illustrate that Russia had limited control over events because developments in the conflict zone diverged from the aims expressed in Moscow's official rhetoric. Few opponents of this narrative would challenge the empirical finding of a divergence between statements and events. What they would challenge, however, is the initial theoretical assumption that diplomatic statements should be considered a reflection of Russian objectives and that the conflict should be analysed through the prism of such statements.

The lack of an overarching theoretical framework means that each of the described explanations for the outbreak of war in the Donbas makes sense, but only within its own frame of reference. Each narrative-whether it stresses the importance of local factors or Russian intervention-may, in fact, accurately describe a certain dimension of the war's causes. However, it is impossible to compare and evaluate the importance of these dimensions and analyse the links between them without a theoretical framework which specifies beforehand what exactly the variety of proposed explanatory factors are supposed to explain.

\section{$4 \quad$ A Donbas Conflict Escalation Ladder}

To address this issue, this article uses an adapted combination of Smoke's definition of escalation and Kahn's ladder analogy as the first conceptual pillar

28 Tetyana Malyarenko and Stefan Wolff, 'The Logic of Competitive Influence-Seeking: Russia, Ukraine, and the Conflict in Donbas', Post-Soviet Affairs 34, no. 4 (2018): 196. In an earlier article, Malyarenko explicitly refers to conflict escalation in the Donbas. However, she does not provide a theoretical discussion or definition of the concept. See Tetyana Malyarenko, 'A Gradually Escalating Conflict: Ukraine from the Euromaidan to the War with Russia', in The Routledge Handbook of Ethnic Conflict, ed. Karl Cordell and Stefan Wolff (London and New York: Routledge, 2016), 349-368.

29 Lance Davies, 'Russia's "Governance" Approach: Intervention and the Conflict in the Donbas', Europe-Asia Studies 68, no. 4 (2016): 726-749; Paul Robinson, 'Russia's Role in the War in Donbass, and the Threat to European Security', European Politics and Society 17, no. 4 (2016): $5^{\circ} 6-521$. 
of a conflict escalation model for the Donbas. ${ }^{30}$ As a first step, it proposes a case-specific escalation ladder (Table 1). Each step on the ladder represents a development which crossed a threshold beyond the limits that previously defined the conflict, which is in line with Smoke's definition of escalation. ${ }^{31}$ At the same time, the ladder follows Angstrom and Petersson's suggestion that Smoke's definition of escalation should be extended to include actions 'both within and outside war', because it includes events before the outbreak of hostilities. ${ }^{32}$

In order to maximize transparency and avoid the theoretical preconceptions affecting the academic literature on the Donbas war, this article refrains from using secondary academic sources as an empirical foundation for its modelling of conflict escalation. Instead, it relies on a comprehensive dataset of online media reports that were published at the time of events. Unlike secondary sources, these media reports consist of real-time information that has not been subject to selection and interpretation in the light of subsequent events. What remains is the potential political bias of the media outlet providing the report. The impact of this, however, can be mitigated through a diverse sample of media sources that represent the views of all major conflict actors.

A first draft of the ladder was created on the basis of a manual, inductive review of a small dataset containing 6,430 media reports from the Ukrainian news website Ukrainska Pravda and the Russian state news agency TASs. These two sources represent the view of a high-profile Ukrainian news outlet with pro-Western views as well as the view of the Russian state. The dataset was gathered using Python programming language code which downloaded all articles containing Donbas-related search terms that were published on the two websites between 22 February and 5 September 2014. This initial draft ladder was then tested and refined by creating keywords relating to each escalation threshold and searching for these keywords in an extended dataset containing 58 , o03 media reports. In addition to the initial small dataset, the extended dataset includes all reports published on the local Donbas news websites Novosti Donbassa, Ostrov, Novorosinform.org, and Novorossia. $s u$, and on the Donbas sections of the Ukrainian newspaper websites Vesti and Segodnya. Novosti Donbassa and Ostrov support a united, pro-European Ukraine. Novorosinform.org and Novorossia.su cover events from the perspective of Russian neo-imperialism, which provided an ideological framework for separatism in the Donbas. Because these two websites only started working

30 Smoke, Controlling Escalation; Kahn, On Escalation.

31 Smoke, Controlling Escalation, 35.

32 Angstrom and Petersson, 'Weak Party Escalation', 287. 
properly in late May 2014, the dataset also includes Vesti and Segodnya. These two sources cover the earliest stages of unrest in the region while being linked to oligarchs who were accused of covertly supporting separatist sentiment in the Donbas.

The result is the refined Donbas escalation ladder shown in Table 1. It cites reports from the extended dataset. In cases where the dataset contains numerous reports on one event, the report containing the most information is cited. Multiple reports are cited when there is no single report that covers all key aspects of an event. When a report consists exclusively of information that was copied from another source outside the dataset and the original source could be easily located, this original source is cited. When a report cites YouTube videos, or when a YouTube search produced videos that provide a better overview over an event than a report from the dataset, these videos are cited instead of the report. ${ }^{33}$

The escalation ladder and the subsequent escalation sequence model are supposed to act as a theoretical framework for more in-depth research on the war's causes. They are not supposed to predetermine the result of such research. For this reason, they remain focused on observable events that are not disputed within the media dataset or the academic literature. As far as possible, they remain agnostic about contentious issues regarding the drivers of these events. ${ }^{34}$

33 This use of data from Internet sources combined with thorough source criticism lies at the heart of what government agencies and journalists often refer to as open source intelligence (OSINT) analysis. A separate publication focusing on this analytic technique and its potential for process tracing research on war is currently under review.

34 Exceptions are instances of cross-border shelling from Russia from July onwards and the intervention of regular Russian troops in late August. Some Russian and pro-Russian activists and media still dispute that these events took place. However, the available evidence is overwhelming and even proponents of domestic causes of the conflict in the academic literature do not dispute these particular episodes of Russian intervention. 


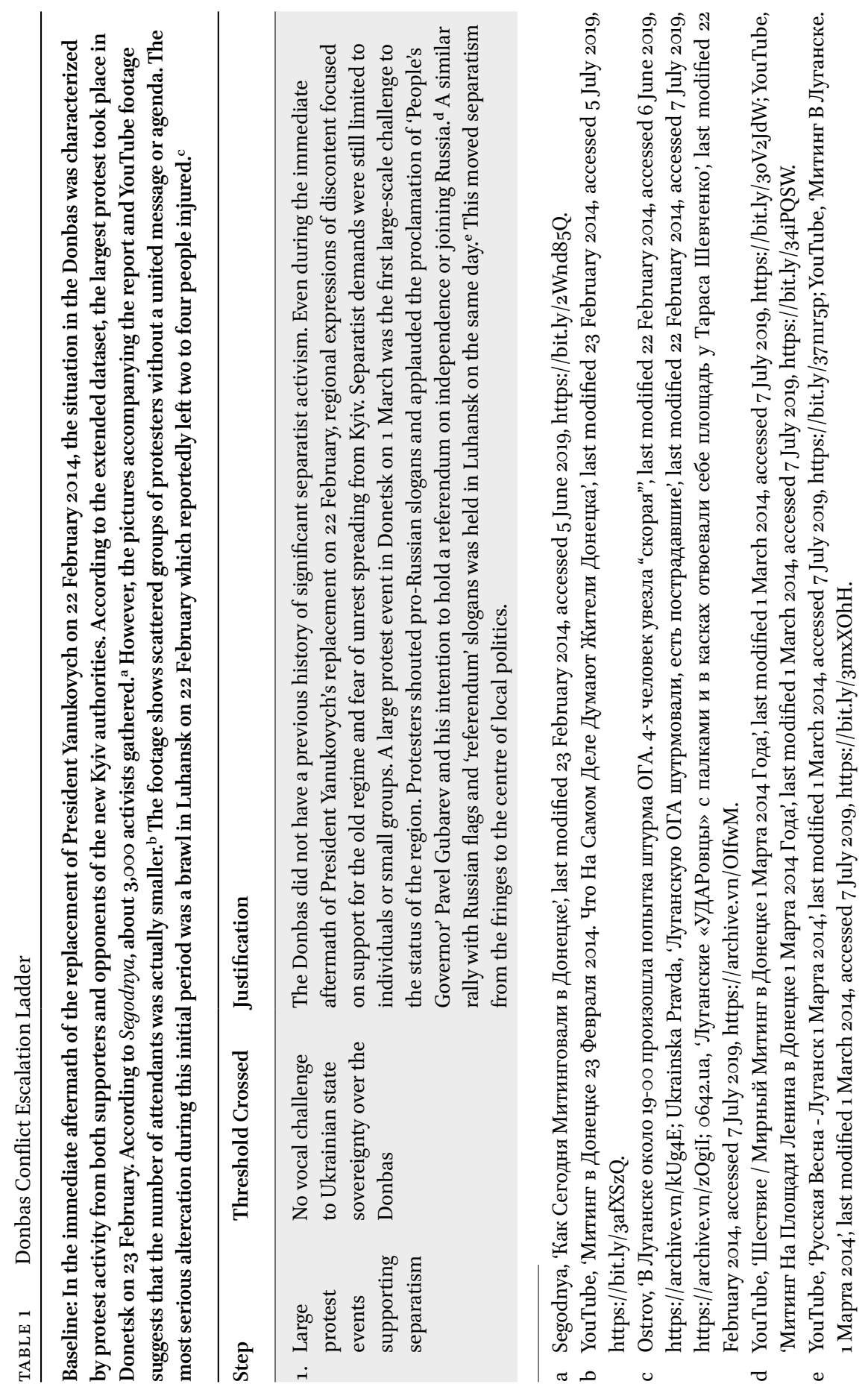




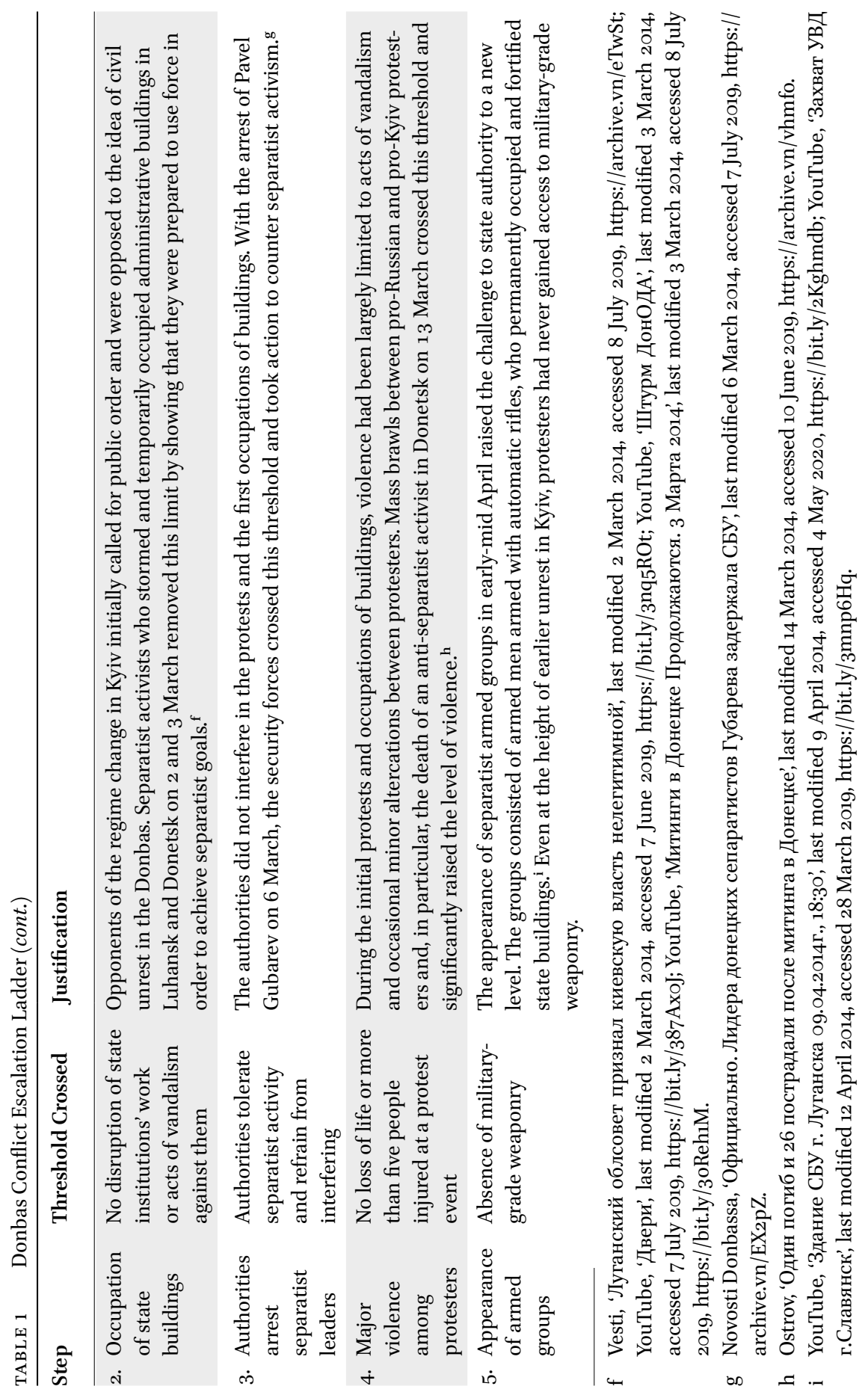




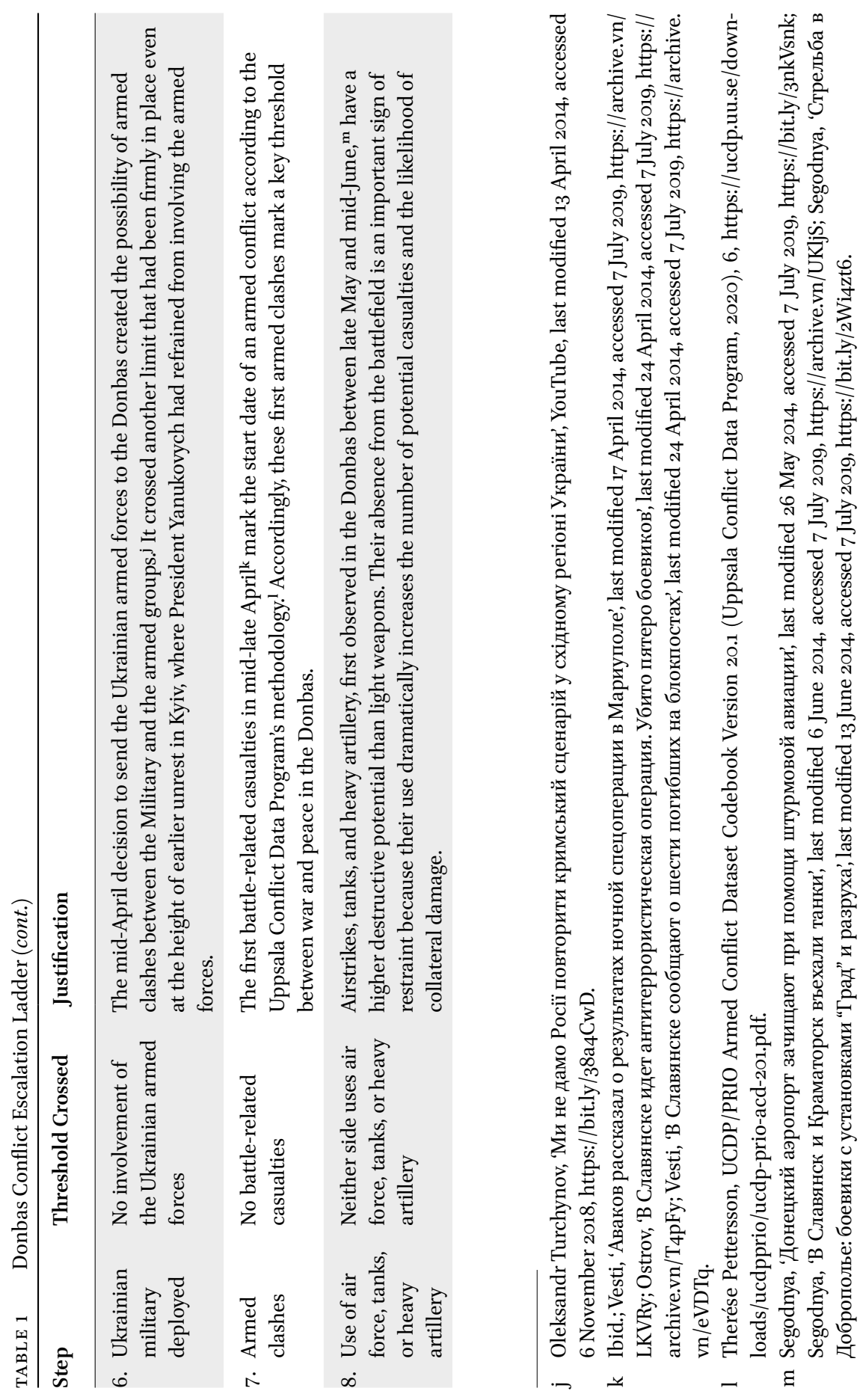




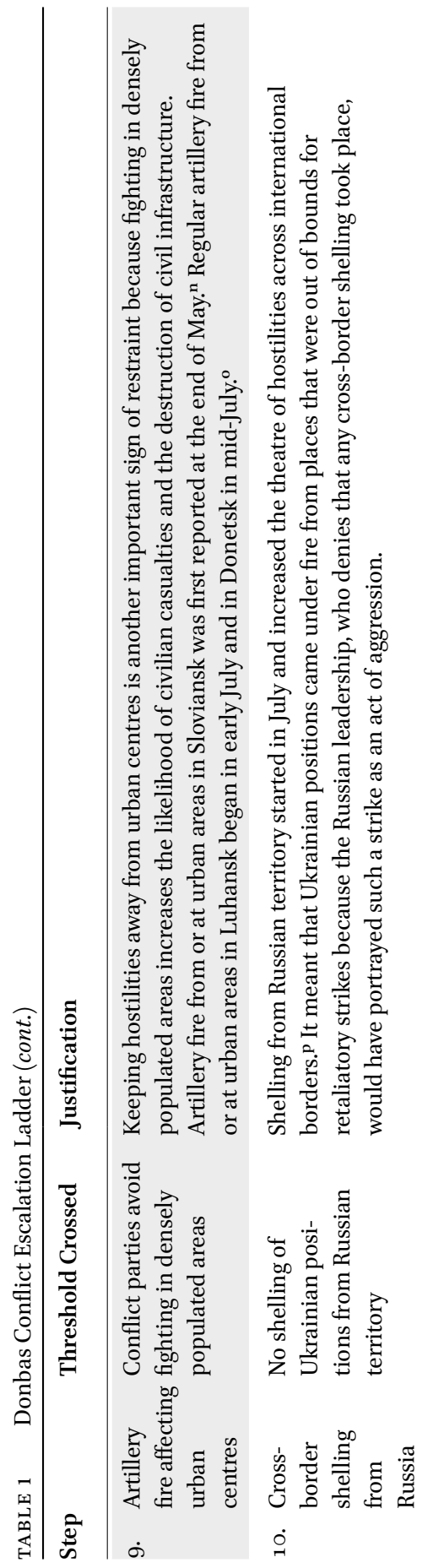

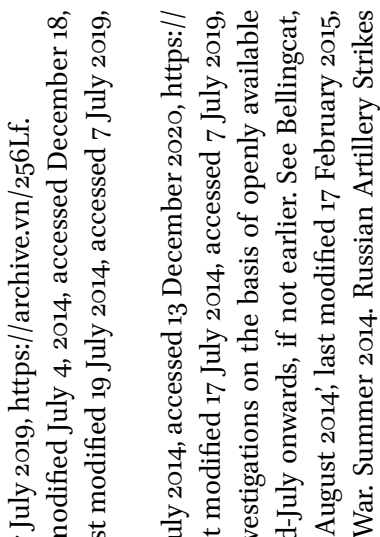

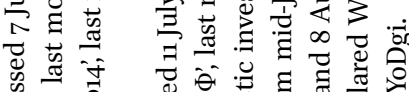

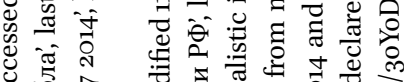

ช 0 O

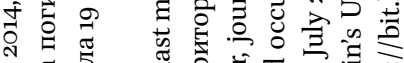

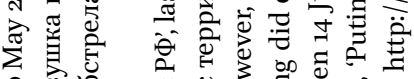

窟

ర

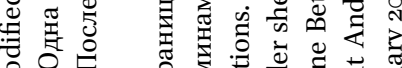

\&

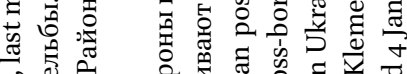

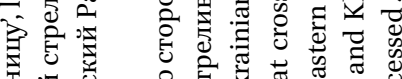

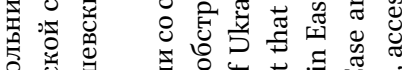

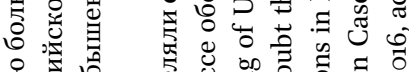

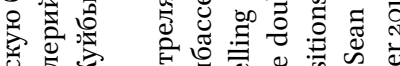

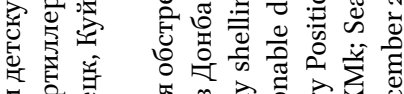

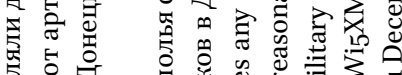

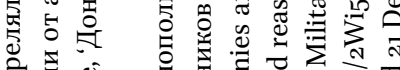

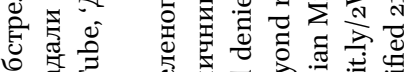

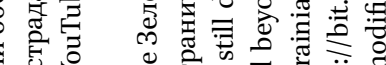

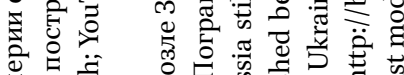

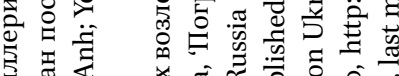

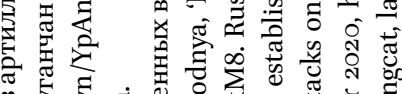

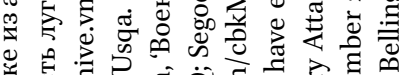

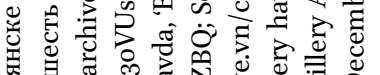

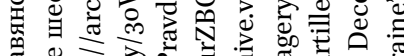

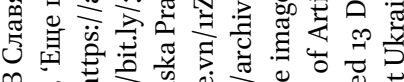

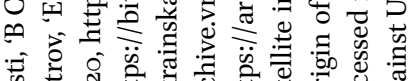

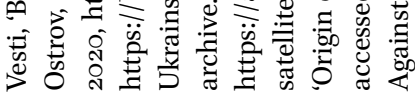

$\Rightarrow 0$ a 


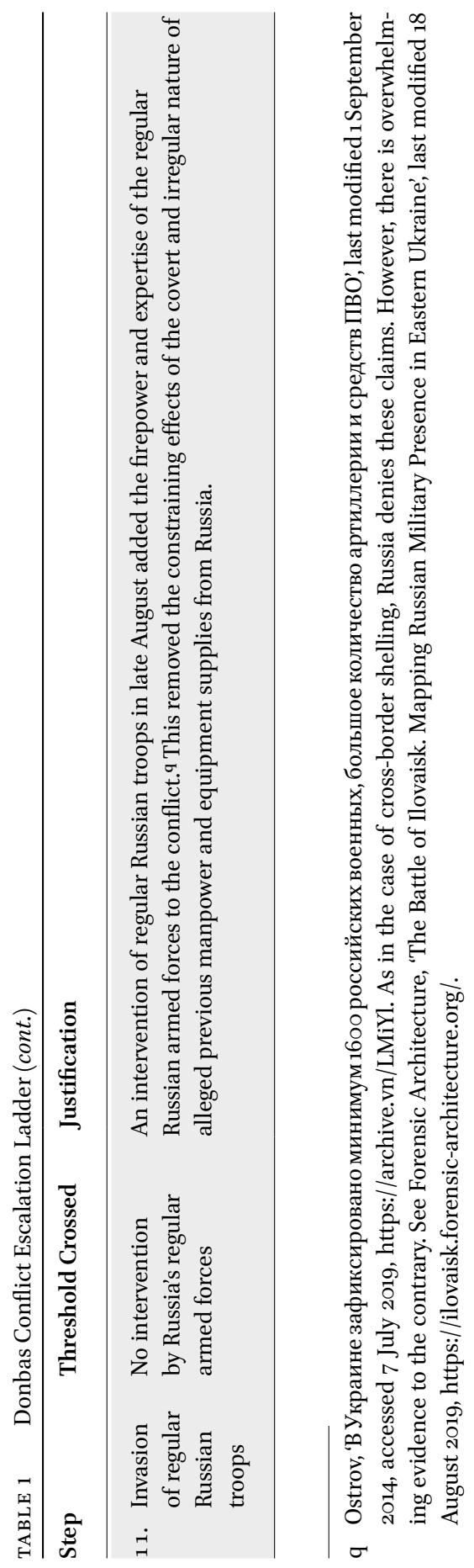




\subsection{Non-Thresholds}

A number of other events have received attention in the literature in the context of the outbreak of the war. At first sight, some of them could be interpreted as escalation threshold crossings. A closer analysis, however, suggests that they were not part of the escalation sequence.

\subsubsection{The Euromaidan Protests}

When investigating the causes of the Donbas conflict, it makes sense to limit the initial analysis to the time after 22 February 2014. Rather than escalating the conflict in the Donbas, the sudden regime change that happened in Kyiv on that day created a baseline from which the conflict could escalate in the first place. This is an important difference. There were no signs of war in the Donbas on 22 February 2014. Manifestations of public discontent were moderate considering that the country had just experienced a revolution. The crucial question of conflict escalation in the Donbas is how the region transitioned from this post-revolutionary state of tense calm to a state of war. An analysis of the previous violence in Kyiv diverts attention from this question and leads to conceptual overstretch. It dissolves the specific issue of the Donbas conflict in a broader analysis. It is clear that the Euromaidan was a necessary condition for the war-just like, for example, the 2012 re-election of Vladimir Putin or the breakdown of the Soviet Union. However, this does not mean that it is useful to view all these preceding events as part of the Donbas conflict. On the contrary, identifying their place in an overarching explanation of the war is only possible after analysing the transition from peace to war in the region itself.

\subsubsection{The Geneva Agreement}

On 17 April 2014, representatives of the European Union, the United States, Ukraine, and Russia issued a statement after multilateral talks in Geneva. ${ }^{35}$ The statement called for the disarmament of all illegal armed groups, the return of all illegally seized buildings, and an inclusive process of constitutional reform in Ukraine. At first sight, the statement could be perceived as an instance of de-escalation. However, when looking at events in the region at the time, it becomes clear that the statement had no discernible de-escalating impact. During the last two weeks of April, the region witnessed unprecedented levels

35 'Geneva Statement on Ukraine', Mission of Ukraine to the North Atlantic Treaty Organization, last modified 17 April 2014, accessed 16 December 2020, https://archive.vn/ vcq7M. 
of violence. ${ }^{36}$ This suggest that scholars who highlight the Geneva Statement ${ }^{37}$ overestimate its significance for the actual course of events.

\subsubsection{The Separatist 'Referenda'}

Other scholars draw attention to the 11 May independence 'referenda' organized by the leadership of the self-proclaimed Donetsk and Luhansk 'People's Republics. ${ }^{38}$ Although these 'referenda' received significant media attention, their significance in terms of conflict escalation was negligible. The two 'Republics' had already been proclaimed. Armed men had already occupied buildings in the regional centres and were engaging in armed combat with Ukrainian security forces in Sloviansk and Mariupol. In this context, a symbolic vote in a number of towns across the region did not represent a step that pushed the level of violence across limits that had previously defined the conflict.

\subsubsection{Events after the First Minsk Agreement}

August 2014 was the deadliest month of the entire war. It was followed by a decrease in the scale and intensity of fighting after the 5 September First Minsk Agreement. ${ }^{39}$ This agreement marks the end of the conflict's initial escalation sequence. Autumn 2014 was a period of relative calm. This was followed by another escalation uptick in early 2015 , which led to the Second Minsk Agreement. ${ }^{40}$ However, fighting did not reach the scale observed in July and August 2014 and, from February 2015 onwards, the war continued to deescalate ${ }^{41}$ Hence, the First Minsk Agreement of September 2014 marks the highest level of escalation observed in the Donbas. It also marks the emergence

36 Ostrov, 'В Славянске идет антитеррористическая операция'; Vesti, 'В Славянске сообщают о шести погибших'; Vesti, 'Аваков рассказал о результатах'.

37 Davies, 'Russia's “Governance” Approach', 735-736; Tetyana Malyarenko and Stefan Wolff, 'The Logic of Competitive Influence-Seeking', 197-199.

38 Robinson, 'Russia's Role in the War in Donbass', 511; Kimitaka Matsuzato, 'The Donbass War: Outbreak and Deadlock', Demokratizatsiya:The Journal of Post-Soviet Democratization 25, no. 2 (2017): 192.

39 OSCE, 'Protocol on the Results of Consultations of the Trilateral Contact Group, Signed in Minsk, 5 September 2014', last modified 5 September 2014, accessed 7 February 2020, https://www.osce.org/home/123257.

40 OSCE, 'Package of Measures for the Implementation of the Minsk Agreements', last modified 12 February 2015, accessed 27 July 2020, https://www.osce.org/cio/140156.

41 For Ukrainian casualty statistics, see 'Загиблі/померлі по місяцях війни', Воok of Memory for the Fallen for Ukraine, accessed 22 July 2020, https://bit.ly/3gT49mj; for a compilation of frontline maps produced by the Ukrainian military, see TSN, ‘ 5 Rokiv Viiny Za 2 Khvylyny', last modified 14 April 2019, accessed 27 July 2020, https://bit.ly/3aeIaFi. 
of the key features that continue to characterize the armed conflict to the time of writing: hostilities of varying but generally decreasing intensity which are contained along a defined contact line that is not subject to significant change. For this reason, it is reasonable to choose 5 September 2014 as the cut-off point for an analysis of the conflict's formative phase. Extending the analysis further to include the subsequent de-escalation process is unlikely to provide significant added value regarding the identification of the conflict's causes.

\section{$5 \quad$ Critical Junctures}

The one-dimensional escalation ladder shown in Table 1 provides a basic framework for the analysis of the Donbas conflict. However, this framework is still too simplistic to be an adequate model of the escalation of violence in the region. It has to be extended to take account of the fact that the actual escalation sequence in the Donbas was spread unevenly across space and time. Different thresholds were crossed in different places at different points in time with the involvement of different actors. In addition to this, the ladder model also has to be extended to address questions of causality. It cannot simply be assumed that it represents a causal sequence in which each step represents a necessary condition for subsequent steps.

A helpful concept to analyse conflict escalation in terms of actors and causality is the historical institutionalist idea of critical junctures. David Collier and Gerardo Munck define a critical juncture as 'a major episode of institutional innovation' which leaves an 'enduring legacy'42 Giovanni Capoccia and Daniel Kelemen add that a critical juncture is short compared to its legacy and that, during a critical juncture, the choices of actors have a higher impact than during the legacy period. ${ }^{43}$ Three of these four criteria apply to all escalation steps. Firstly, an escalation step constitutes a major episode of innovation in an armed conflict because it involves a major change to the implicit rules that restrain violence. Secondly, choices that cross a threshold which defines the current limits of a war are always more impactful than choices that stay within these limits. Thirdly, an act of escalation in war can only leave an enduring legacy if this legacy is long compared to the act itself. Leaving an enduring

42 David Collier and Gerardo L. Munck, 'Building Blocks and Methodological Challenges: A Framework for Studying Critical Junctures', Qualitative \& Multi-method Research 15, no. 1 (2017): 2.

43 Giovanni Capoccia and R. Daniel Kelemen, 'The Study of Critical Junctures: Theory, Narrative, and Counterfactuals in Historical Institutionalism', World Politics 59, no. 3 (April 2007): 348 . 


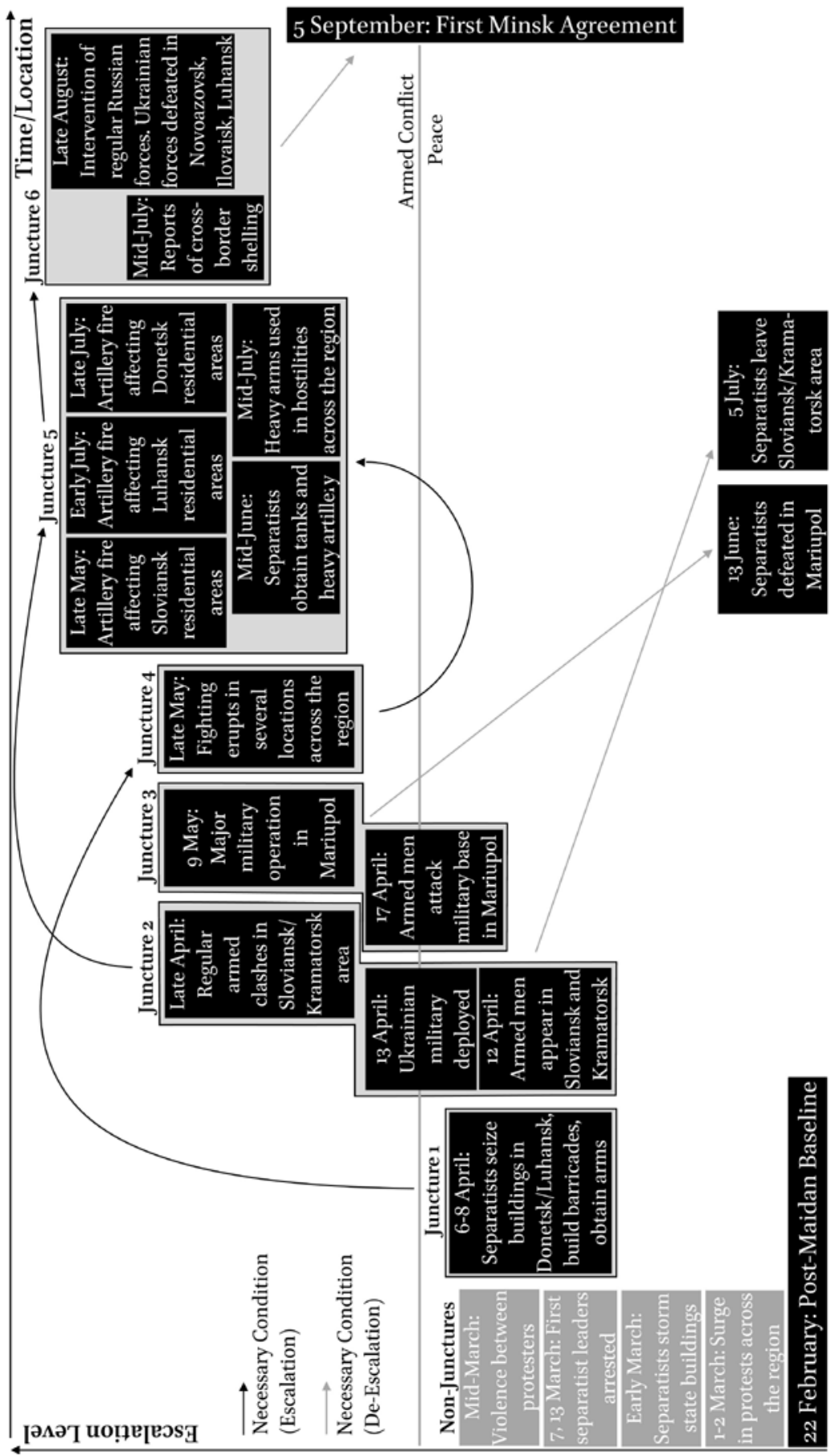


legacy, however, is the key criterion from the definition of critical junctures that is not part of the definition of escalation. In the absence of causal links to subsequent steps, an escalation step could be followed by de-escalation or superseded by further steps without leaving an enduring legacy. Because the legacy requirement brings causation into the equation, it provides added value for the study of escalation.

In the context of the escalation of wars, the enduring legacy has to be a legacy of armed conflict. It can be a legacy of violence, such as hostilities that continue for a long period of time or damage that takes a long time to repair. Alternatively or simultaneously, it can be a legacy of further escalation-a situation that makes additional critical junctures possible which then leave a legacy of violence. Consequently, the enduring legacy criterion is closely linked to causality in terms of necessary conditions. Actors' choices can only leave a legacy on the further course of events if this course of events would not have been the same without their impact. Based on these considerations, the present article divides the escalation of the Donbas conflict into six critical junctures, starting with the armed building occupations of early April 2014 (see Figure 1).

\subsection{Non-Junctures: The Protests of March 2014}

The Donbas escalation ladder (see Table 1) includes events that precede the outbreak of hostilities. In order to qualify as critical junctures, however, such pre-conflict escalation steps would have to be necessary conditions either for the start of the armed conflict or for its subsequent further escalation. A closer look at the relevant events suggests that, up to the building occupations of 6 April 2014, none of the developments in the region meet this criterion.

\subsubsection{Mass Protests Against the Kyiv Authorities}

On the weekend of 1-2 March 2014, large protest rallies against the new Kyiv authorities took place in a number of locations across the Donbas. ${ }^{44}$ The largest rallies were reported from Donetsk and Luhansk with 10,00o people in each city. ${ }^{45}$ However, turnout did not increase further. On the contrary, by April, the protest movement had lost rather than gained momentum. This becomes particularly apparent when comparing videos of the crowd that had gathered in

44 These protests were not limited to the Donbas but also affected other parts of Southeast Ukraine. This article, however, focuses on the Donbas as the only region that witnessed an escalation into armed conflict.

45 Ostrov, 'Митинг в Донецке избрал “народного губернатора”, last modified 1 March 2014, accessed 6 June 2019, https://archive.vn/wExxm; Ostrov, 'Сегодня в центре Луганска собрался “Народный совет Луганщины”, last modified 1 March 2014, accessed 6 June 2019, https://archive.vn/zMwzr. 
front of the Donetsk Regional State Administration on 1 March and 6 April. On the former date, protesters filled the entire square. ${ }^{46}$ On the latter date, they constituted a scattered group of people that only occupied a small section of it. ${ }^{47}$ A calculation of the square's area on Google Earth combined with crowd size models provided by crowd safety expert Keith Still ${ }^{48}$ suggests that 2,00o people is a generous maximum estimate for the 6 April event. Footage from Luhansk from 6 April presents a similar picture. The crowd of protesters was limited to a relatively small area that is unlikely to hold more than 2,00o people. ${ }^{49}$ Gatherings of this size were not significantly above the baseline of protest activity in the Donbas in the immediate aftermath of the replacement of President Yanukovych in late February. Hence, the protest rallies in March do not qualify as a necessary condition for the conflict's further escalation in April. A core group of radicalized activists could have escalated the conflict in April regardless of the scale of earlier protest activity.

\subsubsection{Temporary Occupations of State Buildings}

Initial incidents of protesters storming state buildings in Donetsk and Luhansk in early March were temporary. Activists vacated the occupied buildings after a few hours or days. None of these attempts had a lasting impact, apart from media attention, the arrest of some separatist leaders, and some damage to property. Moreover, there were no reports of building seizures in Donetsk and Luhansk between 16 March and 6 April. This suggests that the events of 6 April—when people stormed buildings, stayed in these buildings, built barricades, and obtained arms - should be analysed as separate events and not as the consequence of previous building occupations.

\subsubsection{The Arrest of Separatist Leaders}

Arresting protest leaders could cause further escalation of a conflict either by radicalizing an initially moderate protest movement or by strengthening

46 YouTube, 'MVI oo94', last modified 1 March 2014, accessed 9 May 2020, https://bit.ly/ 3mtumZY.

47 YouTube, 'В Донецке 6 Апреля 2014 Захват Городской Администрации', last modified 6 April 2014, accessed 9 July 2019, https://bit.ly/3np8MHf; YouTube, 'Донецк 6 Апреля 2014 Часть 5 Народ Штурмует ОблГосАдминистрацию Донецка', last modified 6 April 2014, accessed 24 April 2020, https://bit.ly/2KdwTuj.

48 Keith Still, 'Static Crowd Density Visuals', Crowd Safety and Risk Analysis, last modified 2013, accessed 5 January 2021, http://bit.ly/3bi5emS.

49 YouTube, 'о6 Апреля 2014 Штурм - Захват СБУ Луганской Области', last modified 6 April 2014, accessed 24 February 2020, https://bit.ly/3r5ERpN; YouTube, 'Луганск, o6.04.2014. Захват Здания СБУ', last modified 6 April 2014, accessed 9 May 2020, https:// bit.ly/2Kwd7tS. 
a protest movement because new people join it to demand freedom for those arrested. Neither was the case in the Donbas. Calls for a complete power transfer to the local level and referenda on independence or joining Russia were aimed at conflict escalation from the very beginning. Neither did the arrests of early March galvanize further public support. As argued above, the protest movement lost rather than gained momentum throughout the course of the month.

\subsubsection{Violence Among Protesters}

There is no plausible causal connection between the violence against proEuropean activists at protests in mid-March and the appearance of armed groups. Violence among protesters could have caused further escalation either if protesters had obtained arms as a result or if it had resulted in the security forces using violence to stop further protests from taking place. Neither was the case in the Donbas. The first arms appeared not at protest events but in occupied buildings and at no point did the security forces use violence against protesters.

\subsection{Juncture 1: Donetsk and Luhansk, Early April}

The first critical juncture of the conflict are the events of 6 April. On this day, separatist activists stormed the building of the Regional State Administration in Donetsk and the regional headquarters of the Security Service of Ukraine in Luhansk. Unlike in previous instances of building seizures in the Donbas, the activists did not vacate the buildings again but started building barricades around them. ${ }^{50}$ More importantly, they armed themselves with automatic rifles. ${ }^{51}$ Although it took almost another two months until military combat reached Donetsk and Luhansk, the armed occupation of state buildings in early April created the first militarized separatist footholds in the two cities. Without these footholds, the Ukrainian security forces could have taken control of the regional centres without the risk of armed resistance and civilian casualties. Hence, the initial militarization of separatism in Donetsk and

$5^{\circ}$ Ostrov, 'Захватчики здания СБУ в Луганске возвели баррикады', last modified 7 April 2014, accessed 9 May 2020, https://archive.vn/6ZrEU; YouTube, 'Донецк 8 Апреля 2014', last modified 8 April 2014, accessed 8 July 2019, https://bit.ly/3agyjPe.

$5^{1}$ Novosti Donbassa, 'У сепаратистов в здании Донецкого облсовета находится оружие, захваченное в СБУ', last modified 8 April 2014, accessed 8 July 2019, https://archive .vn/vijVy; 62.ua, 'У сепаратистов в здании Донецкого облсовета находится оружие, захваченное в СБУ', last modified 8 April 2014, accessed 19 May 2020, https://archive.vn/ XJYmi; YouTube, 'Здание СБУ г. Луганска'. 
Luhansk was a necessary condition for the later spread of armed conflict to the two cities, even though the first fighting took place elsewhere.

\subsection{Juncture 2: Sloviansk and Kramatorsk, Mid-Late April}

On 12 April, armed men seized police stations in the towns of Sloviansk and Kramatorsk in the northwest of Donetsk Region. ${ }^{52}$ The following morning, a group of these men attacked Security Service of Ukraine operatives just outside Sloviansk. One person died and several were injured. On the same day, interim President Turchynov announced the launch of an 'antiterrorist operation' with the involvement of the Ukrainian armed forces. ${ }^{53}$ Regular armed clashes in the area commenced in late April. Because this episode of conflict escalation featured the crossing of three thresholds - the appearance of armed groups, deployment of the military, and armed clashes - in close succession, it makes sense to group these events together in one critical juncture. There can be no doubt that the events around Sloviansk left a lasting legacy of armed conflict. For over two months after the outbreak of the armed conflict- until the separatists' withdrawal from Sloviansk on 5 July - the most intense fighting took place in this region. It is also where tanks and heavy artillery were first used. Even if the entire armed conflict had been limited to this time period, it would have left a legacy of violence that was unprecedented in Ukraine since World War II.

\subsection{Juncture 3: Mariupol-Where Separatism Failed}

After Sloviansk, the southern port city of Mariupol was the first place in the Donbas where tensions crossed the armed conflict threshold. ${ }^{54}$ Like in the Sloviansk area, the appearance of armed groups, the deployment of the security forces, and the first armed clashes happened in close succession. However, the level of violence and separatist control never reached the level observed in other areas and the Kyiv authorities re-consolidated their control over the city

$5^{2}$ YouTube, 'Захват УВД г.Славянск’; YouTube, 'Краматорск, Захват Отдела МВД', last modified 13 April 2014, accessed 28 March 2019, https://bit.ly/3gT145L.

53 Hromadske TV, ‘Слов’янськ. Місце Бою', YоuTube, last modified 13 April 2014, accessed 11 July 2019, https://bit.ly/37oO3oX; LifeNews, 'Видео после перестрелки под Славянском осторожно, в кадре есть убитые', YouTube, last modified 13 April 2014, accessed 26 March 2019, https://bit.ly/34kı2Ph; LifeNews, 'Life News о Бое 13 Апреля 2014 г. Возле Пос. Семеновка', YоuTube, last modified 13 April 2014, accessed 11 July 2019, https://bit .ly/34lrTKO; Turchynov, 'Ми не дамо Росії повторити кримський сценарій'.

54 Novosti Donbassa, '7 убитых, 39 раненых в Мариуполе 9 мая', last modified 9 May 2014, accessed 8 July 2019, https://archive.vn/h8ee5; Vesti, 'Аваков рассказал о результатах’; Vesti, 'В Мариуполе 9 мая погибли семь человек и 39 пострадали', last modified 9 May 2014, accessed 8 July 2019, https://archive.vn/kdygt. 
as early as mid-June. ${ }^{55}$ Nevertheless, the fighting that occurred left a legacy of armed conflict.

\subsection{Juncture 4: The Fighting Spreads, Late May}

From late May onwards-around the time of the Ukrainian presidential election-hostilities rapidly spread to several other locations across the Donbas. The most important new theatres of violence were Volnovakha, ${ }^{56}$ Karlivka, ${ }^{57}$ Donetsk Airport, ${ }^{58}$ parts of Luhansk city, ${ }^{59}$ an urban agglomeration northwest of Luhansk, ${ }^{60}$ and rural areas near the Russian-Ukrainian border in the south of Donetsk and Luhansk Regions. ${ }^{61}$ This sudden increase in the theatre of war paved the way for continuing hostilities in these new hotbeds, including the use of tanks and heavy artillery. Potentially, each incident of fighting spreading to a new location could be defined as a separate critical juncture. However, to avoid fragmentation of the model, it makes sense to group these incidents together.

\subsection{Juncture 5: Tanks and Heavy Artillery, June-July}

The Ukrainian armed forces first used airstrikes during armed clashes at Donetsk Airport on 26 May. ${ }^{62}$ The use of heavy artillery was first reported

55 Novorosinform.org, 'Каратели устроили в Мариуполе зачистку', last modified 13 June 2014, accessed 8 July 2019, https://archive.vn/KTxGw; Liga.Novosti, 'Террористы не смогут вернуться в Мариуполь', last modified 13 June 2014, accessed 8 July 2019, https:// archive.vn/pqRjW.

56 Ostrov, 'Уточненные данные. В бою под Волновахой погибли 16 человек', last modified 22 May 2014, accessed 8 July 2019, https://archive.vn/jHjDq.

57 Novosti Donbassa, 'Число жертв боя под Карловкой больше, чем сообщают официальные источники', last modified 24 May 2014, accessed 8 July 2019, https://archive .vn/Ei44U.

58 TASS, 'Мэр Донецка Подтвердил Гибель 40 Человек в Результате Спецоперации Киева', last modified 27 May 2014, accessed 8 July 2019, https://archive.vn/ASmYt.

59 Novosti Donbassa, 'В Луганске продолжается бой пограничников с террористами', last modified 2 June 2014, accessed 8 July 2019, https://archive.vn/rbGNS; TASS, 'Погранслужба Украины Заявила о Штурме Ополченцами Управления Луганского Погранотряда', last modified 2 June 2014, accessed 8 July 2019, https://archive.vn/ $/ \mathrm{X}_{7}$ Eh5.

60 Ukrainska Pravda, '1 военный погиб и 3 ранены в бою между Рубежным и Дружелюбовкой', last modified 23 May 2014, accessed 16 December 2020, https://archive .vn/uYjmo.

61 Novosti Donbassa, 'На блокпосте в Донецкой области военные отбили атаку террористов', last modified 19 May 2014, accessed 8 July 2019, https://archive.vn/hNJHD; Glavkom, 'В приграничном селе на Луганщине ожесточенный бой', last modified 13 June 2014, accessed 3 August 2020, http://bit.ly/37oRapC.

62 Segodnya, 'Донецкий аэропорт зачищают'. 
near Sloviansk on $29 \mathrm{May}^{63}$ and the combat deployment of Ukrainian tanks in this region was confirmed on 6 June. ${ }^{64}$ In mid-June, first reports of tanks and artillery under separatist control appeared. ${ }^{65}$ Soon, the use of tanks and heavy artillery on both sides became a common occurrence across the battlefield and, simultaneously, began to affect densely populated areas. Heavy arms left a particularly devastating legacy, because they were responsible for most of the damage and loss of life in the Donbas during the course of the armed conflict.

\subsection{Juncture 6: Intervention of Regular Russian Forces, Late August}

The Ukrainian armed forces first voiced allegations of cross-border shelling from Russian territory in mid-July after an attack on Ukrainian positions near the village of Zelenopillia. ${ }^{66}$ This attack and subsequent incidents of cross-border shelling may have slowed the advance of the Ukrainian forces, but they were insufficient to turn the tide of the conflict. When the Ukrainian advance was reversed in late August and the separatists regained control over the areas south of Luhansk, southeast of Donetsk, and east of Mariupol, Kyiv claimed that a major Russian invasion force was responsible for this sudden defeat. ${ }^{67}$ Moscow denies all of these claims, but there is overwhelming evidence to the contrary. ${ }^{68}$ At the same time, it is clear that Russia's actions during this phase were a necessary condition for the continuation of the armed conflict over the years that followed because they prevented Ukrainian forces from regaining control over the conflict zone. Hence, it is clear that Russia played the determining role in the last critical juncture of the war's formative stage. What remains open, however, is the question whether Russia's role as the primary conflict driver was limited to this final episode of the war's escalation sequence.

63 Ostrov, 'В Славянске и Краматорске полномасштабная ATO', last modified 29 May 2014, accessed 8 July 2019, https://archive.vn/d4Ueo.

64 Segodnya, 'В Славянск и Краматорск въехали танки'.

65 YouTube, 'Макеевка. Колонна Танков. 12.06.14', last modified 12 June 2014, accessed 8 July 2o19, https://bit.ly/34fozAY; Segodnya, 'Стрельба в Доброполье'.

66 Ukrainska Pravda, 'Военных возле Зеленополья обстреляли'.

67 Ostrov, 'В Украине зафиксировано минимум 16оо российских военных'.

68 Bellingcat, 'Origin of Artillery Attacks on Ukrainian Military Positions'; Case and Anders, 'Putin's Undeclared War'; Forensic Architecture, 'The Battle of Ilovaisk'. 
This article has combined conflict escalation theory and the concept of critical junctures to model the escalation sequence of the war in eastern Ukraine's Donbas (see Figure 1). The proposed model highlights six critical junctures which are the key stepping-stones in the genesis of this war:

1. The first armed building occupations in Donetsk and Luhansk in early April

2. The appearance of armed militias and the outbreak of fighting in the Sloviansk area in mid-late April

3. Armed clashes in Mariupol between April-June

4. The sudden spread of fighting across several other parts of Donetsk and Luhansk Regions in late May

5. The use of tanks and heavy artillery across the different battlefields from mid-June onwards

6. The defeat of the advancing Ukrainian forces in late August by the Russian military

In the case of the Donbas, this model can help resolve the key point of contention that divides the academic debate-whether the Ukrainian forces are fighting a hostile neighbouring state or aggrieved local residents. The model is compatible with arguments from either side of this controversy. ${ }^{69}$ Therefore, it acts as a benchmark for hypothetical causes of the war-be they grievances within the local population, the actions of local elites, or Russian interference. Future research can measure the explanatory power of each of these factors against the extent to which they can explain the outlined escalation sequence.

In other words, the present article has engaged in theory-guided 'explainingoutcome process tracing. ${ }^{70}$ Its escalation sequence model represents a causal mechanism that links the war in the Donbas as an outcome to its potential causes. For this reason, the model forces researchers investigating these causes to focus on the process of conflict escalation instead of second-guessing the conflict's nature by analysing circumstantial conditions like the region's history, local public opinion, or geopolitical constellations. It also prevents researchers from choosing a theoretical framework that avoids the question or predetermines the result. For these reasons, the present model has the potential to

69 Presuming that they acknowledge the fact that Russia carried out cross-border shelling from mid-July onwards and intervened with regular troops in late August.

70 Derek Beach and Rasmus Brun Pedersen, Process-Tracing Methods: Foundations and Guidelines (Ann Arbor: The University of Michigan Press, 2013), 18-21. 
facilitate an explanation for the Donbas conflict that is transparent, comprehensive, and theory-guided. Such an explanation could then feed into a higherlevel discourse and inform both comparative research and policy making.

These advantages of the proposed model are by no means limited to the specific controversy surrounding the case of the Donbas. The benefits of the present study can be easily transferred to other cases because the roadmap that it uses to create its escalation sequence model is universally applicable. The creation of an escalation table containing the different thresholds which crossed conflict-defining limits of violence and the subsequent identification of critical junctures among these thresholds can be repeated for any other war. This applies to contemporary conflicts as well as historical cases. A detailed escalation sequence model could, for example, shed additional light on the role of different rebel groups, government forces, and either side's foreign sponsors during the war in Syria. At the same time, a model like the one proposed in this article could also be used to revisit the age-old debate on the causes of World War I. Moreover, the present escalation model can translate different methods of data collection into a common framework. Depending on the information environment that surrounds a particular conflict, a variety of data sources can be used to identify escalation thresholds and critical junctures. This article uses open source intelligence (OSINT) by exploiting a dataset of online news media as well as videos of relevant events uploaded to social media. Other studies may create escalation tables and escalation graphs on the basis of eyewitness interviews, archival documents, secondary accounts of historians, or a combination of different sources.

As a result, the creation of escalation sequence models for a number of different conflicts could create promising new opportunities for comparative research on the causes of war. Even though every case of conflict escalation has its own case-specific nuances, it is possible that the comparison of different conflict escalation models will show certain similarities between them. To use Dessler's thunderstorm metaphor, each conflict escalation model provides an insight into the processes inside gathering storm clouds during the formation of a specific storm. ${ }^{71}$ Although the processes at work in the escalation of armed conflict are highly unlikely to follow laws of nature in a way that is comparable to thunderstorm formation, certain patterns and common features may still become apparent. Potentially, a comparison of these processes could reveal certain commonalities that could feed into something resembling Dessler's idea of 'causal theory of war'. Naturally, the case-specific conflict escalation sequence model proposed in this article is only a small step in this direction.

71 Dessler, 'Beyond Correlations', 342-344. 
Nevertheless, it is an avenue worth pursuing. Moreover, even if its application to other cases does not directly lead to generalizable findings regarding the causes of war, the theoretical framework proposed in this article will remain an important case-focused supplement to comparative research. It builds a bridge between the focus on case-specific circumstances, which characterizes the work of most historians and Area Studies specialists, and the need for generalization and streamlining in comparative social science research. In addition to building this bridge between the specific and the general, the proposed model facilitates comparison and communication among scholars who focus on the relative importance of and the interactions between different explanatory factors within case-studies. Academic research on the causes of war can only benefit from a common frame of reference of this kind.

\section{Acknowledgements}

The author would like to thank two anonymous reviewers for their helpful comments which greatly improved the present article. He would also like to thank his PhD supervisors, Professor Andrew Wilson and Dr Ben Noble, for encouraging him to publish this article and for their feedback on earlier drafts. 